\title{
Is al het weerloze van waarde?
}

Citation for published version (APA):

van der Aa, S. (2020). Is al het weerloze van waarde? Over het kwetsbare slachtoffer in het straf(proces)recht. Maastricht University. https://doi.org/10.26481/spe.20201127sa

Document status and date:

Published: $27 / 11 / 2020$

DOI:

10.26481/spe.20201127sa

Document Version:

Publisher's PDF, also known as Version of record

\section{Please check the document version of this publication:}

- A submitted manuscript is the version of the article upon submission and before peer-review. There can be important differences between the submitted version and the official published version of record.

People interested in the research are advised to contact the author for the final version of the publication, or visit the DOI to the publisher's website.

- The final author version and the galley proof are versions of the publication after peer review.

- The final published version features the final layout of the paper including the volume, issue and page numbers.

Link to publication

\footnotetext{
General rights rights.

- You may freely distribute the URL identifying the publication in the public portal. please follow below link for the End User Agreement:

www.umlib.nl/taverne-license

Take down policy

If you believe that this document breaches copyright please contact us at:

repository@maastrichtuniversity.nl

providing details and we will investigate your claim.
}

Copyright and moral rights for the publications made accessible in the public portal are retained by the authors and/or other copyright owners and it is a condition of accessing publications that users recognise and abide by the legal requirements associated with these

- Users may download and print one copy of any publication from the public portal for the purpose of private study or research.

- You may not further distribute the material or use it for any profit-making activity or commercial gain

If the publication is distributed under the terms of Article $25 \mathrm{fa}$ of the Dutch Copyright Act, indicated by the "Taverne" license above, 
Dr. Suzan van der Aa

Faculteit der Rechtsgeleerdheid

Is al het weerloze van waarde?

Over het kwetsbare slachtoffer in het straf(proces)recht 


\section{Is al het weerloze van waarde?}

\section{Over het kwetsbare slachtoffer in het straf(proces)recht}

Beste aanwezigen en beste kijkers thuis. Voordat ik overga tot het uitspreken van mijn oratie, wil ik beginnen met een kort dankwoord aan jullie. Allereerst wil ik de mensen hier in de aula bedanken voor jullie komst. Jullie aanwezigheid in deze omstandigheden is zeker niet vanzelfsprekend en dat jullie hier vandaag toch zijn wordt erg gewaardeerd. Maar ook alle kijkers die de ceremonie nu noodgedwongen via de computer moeten volgen wil ik bedanken. Het is nu even lastig, maar het "live" proosten houden we gewoon tegoed.

Ik ga beginnen.

\section{Inleiding}

'Is al het weerloze van waarde?' is de titel van mijn oratie en velen van jullie hebben hierin ongetwijfeld een variatie herkend op de beroemde regel uit het gedicht 'De zeer oude zingt' van Lucebert:

\section{alles van waarde is weerloos wordt van aanraakbaarheid rijk en aan alles gelijk}

$\mathrm{Nu}$ zie ik enkele vrienden en familieleden al bedenkelijk kijken: Zij hebben mij nog nooit betrapt op het lezen van een dichtbundel en nu kom ik ineens met Lucebert aanzetten. Hen wil ik geruststellen: ingewikkelder dan dit gaat het de komende 45 minuten niet worden. Maar dit gedicht is relevant voor hetgeen ik hierna ga vertellen.

Deze beroemde regel is zo vaak geciteerd dat we er collectief een blinde vlek voor hebben ontwikkeld. De inhoud wordt bekend verondersteld. Welnu, een vergelijkbare blinde vlek hebben we volgens mij ook wanneer het gaat over kwetsbare slachtoffers binnen het strafrecht. Sommige kwetsbaarheden zijn zo vanzelfsprekend dat ze nauwelijks ter discussie staan. Denk bijvoorbeeld aan mensen met een verstandelijke beperking en kinderen. Maar ook nieuwe groepen 'kwetsbaren' - zoals ouderen - worden soms vrijwel kritiekloos en $a$ priori als kwetsbaar aangemerkt.

Nu zijn natuurlijk alle slachtoffers in zekere zin kwetsbaar. Maar de laatste decennia is er binnen het nationale, Europese en internationale strafrecht een trend ontstaan om bepaalde groepen slachtoffers te identificeren die als extra kwetsbaar worden gezien. En die speciale behoeften hebben ten aanzien van het procedurele of materiële strafrecht. Om aan deze speciale behoeften tegemoet te komen zijn op deze slachtoffers extra maatregelen van toepassing in aanvulling op de algemene slachtofferrechten. Wanneer ik in het navolgende spreek over 'kwetsbare slachtoffers', dan bedoel ik juist deze bijzonder kwetsbare slachtoffers. 
Of iemand als kwetsbaar wordt gezien kan belangrijke gevolgen hebben voor slachtoffers. Zo kan het bijvoorbeeld bepalen of je al dan niet beschermd wordt tegen de verdachte, of je toegang hebt tot gespecialiseerde hulpverlening, of je mag spreken tijdens de zitting, of je gebruik kunt maken van gratis rechtsbijstand, of je een voorschot betaald krijgt en het kan zelfs van invloed zijn op de straftoemeting.

Vanwege de trend om aparte groepen slachtoffers te identificeren als bijzonder kwetsbaar en hen te voorzien van aanvullende rechten is een zogenaamde 'slachtofferhiërarchie' ontstaan. $\mathrm{Er}$ is sprake van een geprivilegieerde behandeling van bepaalde groepen slachtoffers. Dit gebeurt echter zonder dat er altijd voldoende aandacht wordt geschonken aan het concept kwetsbaarheid, aan het verband tussen een bepaalde kwetsbaarheid en de daaraan gekoppelde extra maatregelen, en aan de rechtvaardiging van dergelijke privileges ten opzichte van de 'reguliere' slachtoffers.

Het groeiend aantal kwetsbare groepen en speciale maatregelen binnen het strafrecht nopen tot een nadere analyse van het concept kwetsbaarheid. Welke kwetsbaarheden worden momenteel erkend binnen het materiële en het formele strafrecht? Waarom zijn deze kwetsbaarheden gekozen (en andere niet) en hoe zit het met empirisch onderzoek naar deze kwetsbaarheden? Welke kwetsbaarheden zien we mogelijk over het hoofd of welke kwetsbaarheden zijn - bij nader inzien - misschien minder relevant?

Oftewel: Is al het weerloze van waarde?

Ik signaleer verschillende problemen met de huidige 'kwetsbare slachtofferhiërarchie', waarvan ik er vandaag vier met jullie wil bespreken:

1) Allereerst het probleem dat de classificatie van bepaalde groepen als extra kwetsbaar soms incoherent en intransparant is. Kwetsbaarheden die bij de ene groep van belang worden geacht, zijn dat bij een andere groep ineens niet, zonder dat duidelijk is waarom. Dit leidt tot ongelijkheid tussen slachtoffers en tot situaties van zowel overals onderbescherming.

2) Het tweede probleem ziet op het feit dat de classificatie van kwetsbare of "reguliere" slachtoffers soms gebeurt op basis van aannames en stereotype ideeën die we bij bepaalde groepen in de samenleving hebben. Deze ideeën worden niet altijd gestaafd aan de hand van empirisch bewijsmateriaal en kunnen wederom leiden tot ongelijkheid en tot over- en onderbescherming.

3) Ten derde kan betrokkenheid van een kwetsbaar slachtoffer ook van invloed zijn op de sanctionering. De bijzondere kwetsbaarheid van het slachtoffer wordt steeds vaker in strafverhogende zin gebruikt. Het is de vraag of dit soms niet te snel gebeurt.

4) Ten vierde kan de kwalificatie als extra kwetsbaar ook allerlei ongewenste neveneffecten hebben voor de kwetsbare slachtoffers zelf. Zo willen bepaalde slachtoffers misschien helemaal niet als kwetsbaar worden gezien, kan het alsmaar aanduiden van bepaalde groepen als 'kwetsbaar' leiden tot een self-fulfilling prophecy en krijgen sommige slachtoffers te maken met paternalisme en maatregelen die juist in hun nadeel werken. 
Ik zal tijdens deze oratie dieper ingaan op deze vier knelpunten, maar eerst wil ik het kort hebben over het concept kwetsbaarheid zelf.

\section{Het concept kwetsbaarheid}

$\mathrm{Er}$ is inmiddels behoorlijk wat geschreven over kwetsbaarheid, maar een van de bekendste kwetsbaarheidstheoretici is Martha Fineman en haar theorie van de universele kwetsbaarheid. Ik ga nu met zevenmijlslaarzen door deze theorie heen. Voor een uitgebreider beschrijving verwijs ik graag naar de geschreven versie van deze oratie. Die zal in de loop van volgend jaar verschijnen.

Volgens Fineman is kwetsbaarheid een universele ervaring, in de zin dat iedereen kwetsbaar is. Het is een constant en een onvermijdelijk aspect van de menselijke ervaring. Dit heeft te maken met onze 'menselijke belichaming'. We bestaan nu eenmaal allemaal uit botten en wat organen en we krijgen allemaal te maken met ziekte en de dood. We zijn bovendien afhankelijk van anderen om te kunnen functioneren en onze doelen te bereiken Kwetsbaarheid wordt een probleem op het moment dat onze behoefte aan ondersteuning en hulp van anderen groter is dan het aanbod.

Volgens Fineman, dient de staat responsief te zijn voor wat betreft die universele kwetsbaarheid en dient de staat gelijkheid tussen mensen te bevorderen. Bijvoorbeeld door ervoor te zorgen dat de middelen die nodig zijn om veerkrachtig te worden eerlijk worden verdeeld.

Fineman is in beginsel avers van het idee van 'identiteitsgroepen'. Het idee dat enkel bepaalde subgroepen kwetsbaar zijn is volgens haar misleidend en schadelijk. Het geeft ten onrechte de indruk dat velen onkwetsbaar zijn, namelijk degenen die niet binnen een kwetsbare subcategorie vallen. Toch moet ook Fineman toegeven dat bepaalde groepen binnen de samenleving in een achtergestelde positie verkeren en dat niet iedereen in dezelfde mate en op dezelfde wijze kwetsbaar is. Sommige groepen lopen nu eenmaal grotere risico's en dat rechtvaardigt speciale aandacht voor deze groepen. De crux is echter om deze speciale aandacht van een goede en transparante rechtvaardiging te voorzien.

De 'universele kwetsbaarheid' van Fineman heeft veel navolging gekregen, maar er is ook een alternatieve stroming waarneembaar binnen de kwetsbaarheidsliteratuur. Deze auteurs propageren juist een 'minderhedenmodel van kwetsbaarheid'. Zij beschouwen bepaalde groepen als inherent kwetsbaar op basis van bepaalde gemeenschappelijke eigenschappen. Denk bijvoorbeeld aan kinderen die altijd zijn. De meerderheid van de populatie wordt echter als niet-kwetsbaar gezien en wordt beschouwd als een groep die het ook zonder extra bescherming kan stellen. Binnen deze stroming is kwetsbaarheid dikwijls binair - je bent kwetsbaar of je bent het niet - en deze classificatie hangt vrijwel automatisch vast aan je 'lidmaatschap' van een bepaalde groep.

Het uitgangspunt dat de meerderheid van de bevolking niet-kwetsbaar is versus het uitgangspunt dat iedereen kwetsbaar is, heeft belangrijke implicaties voor het recht. Het is interessant om aan de hand van de beide 'stromingen' ons Nederlandse stelsel onder de loep te nemen. Welk kwetsbaarheidsmodel staat in ons strafrecht centraal? 
Om hier achter te komen zal ik eerst kort schetsen welke categorieën kwetsbare slachtoffers het strafrecht kent, wat de ratio is achter de kwalificatie en wat de daaraan gekoppelde bijzondere maatregelen beogen te bewerkstelligen.

\section{Kwetsbaarheid binnen het Nederlandse formele en materiële strafrecht}

Zowel binnen het formele strafrecht, als het materiële strafrecht worden steeds meer nieuwe groepen 'kwetsbaren' onderscheiden. Dat varieert van minderjarige slachtoffers, slachtoffers van ernstige misdrijven, slachtoffers met een beperking tot oudere slachtoffers. Om jullie een indruk te geven heb ik op de powerpoint enkele categorieën kwetsbare slachtoffers en enkele bijzondere maatregelen weergegeven, maar er zijn er nog meer

En de lijst blijft waarschijnlijk maar groeien. De Europese Commissie noemde in haar nieuwste Victim Strategy bijvoorbeeld milieuslachtoffers als kwetsbare groep. En als het aan politieke partij 50Plus ligt, wordt ook de bescherming van oudere slachtoffers in de toekomst steviger verankerd. De partij pleit in haar recent verschenen concept-verkiesprogramma voor strengere straffen voor geweldsdelicten tegen ouderen en mensen met een kwetsbare gezondheid.

Zojuist ging het over de onderscheiden groepen kwetsbare slachtoffers, maar daarmee is nog niet vastgesteld waarom deze groepen als extra kwetsbaar worden gezien. De argumenten die worden gebruikt om de selectie te rechtvaardigen kunnen grofweg worden geclusterd in vier categorieën:

- Problemen met begrijpen of begrepen worden. Het strafproces is voor de gemiddelde rechtsgenoot al lastig te doorgronden, maar dit geldt nog meer voor bepaalde slachtoffers, zoals verstandelijk beperkten of mensen die geen Nederlands spreken. Maatregelen als bijstand door een tolk of het inzetten van gespecialiseerde verhoorders beogen deze slachtoffers beter in staat te stellen de procedure te begrijpen of zelf begrepen te worden.

- Groter risico op secundaire victimisatie. Sommige slachtoffers hebben allerlei bijzondere behoeften ten aanzien van de strafprocedure. Wanneer hier onvoldoende aan wordt tegemoetgekomen, dan kan dat leiden tot 'secundaire victimisatie'. lemand wordt in dat geval niet alleen slachtoffer van het delict, maar wordt daarna nogmaals slachtoffer, maar ditmaal door de inadequate reactie vanuit de strafrechtsketen. Maatregelen als een speciale case manager of verhoor door personen van hetzelfde geslacht als het slachtoffer beogen dit te voorkomen.

- Groter risico op primair slachtofferschap. Sommige mensen lopen dan weer een groter risico om überhaupt slachtoffer van een strafbaar feit te worden. Of om herhaald gevictimiseerd te worden. Denk bijvoorbeeld aan slachtoffers van huiselijk geweld. Beschermingsmaatregelen tegen de dader, maar ook hogere strafmaxima staan in het teken van preventie van het primaire slachtofferschap.

- Groter risico op ernstige impact van het misdrijf. Bepaalde kwetsbaarheden kunnen tenslotte ook van invloed zijn op de impact van een strafbaar feit op een slachtoffer. 
Verschillende maatregelen, zoals bijvoorbeeld het spreekrecht, proberen ervoor te zorgen dat het kwetsbare slachtoffer sneller herstelt.

\subsection{Kwetsbare minderheden of universele kwetsbaarheid?}

Wanneer we nu kijken naar de manier waarop binnen het strafrecht kwetsbare slachtoffers worden geconceptualiseerd, dan zien we zowel trekken uit de universaliteitsgedachte van Martha Fineman, als trekken uit het binaire minderhedenmodel terug.

De algemene slachtofferrechten, die gelden voor alle slachtoffers, kunnen worden gezien als een erkenning van het feit dat alle slachtoffers in zekere zin kwetsbaar zijn. En dat ze allemaal een zeker risico lopen op secundair slachtofferschap. De algemene slachtofferrechten kunnen dan ook worden geplaatst in het universaliteitsmodel.

Wanneer we echter kijken naar de bijzondere maatregelen die gelden voor kwetsbare slachtoffers, dan valt op dat er doorgaans wordt uitgegaan van het binaire minderhedenmodel. Dit is met name het geval bij minderjarige slachtoffers: zij worden automatisch als kwetsbaar gezien. Maar ook voor wat betreft de uitoefening van het spreekrecht, het recht op gratis rechtsbijstand, een uitkering vanuit het Schadefonds Geweldsmisdrijven of de voorschotregeling zijn de categorieën slachtoffers die hier gebruik van kunnen maken strikt afgebakend. Wanneer je tot de kring van gerechtigden behoort, heb je toegang tot deze rechten, wanneer dat niet zo is, heb je pech.

Toch zijn er ook bijzondere maatregelen in ons stelsel die eerder de universaliteitsgedachte lijken te omarmen. Neem bijvoorbeeld de recent geïntroduceerde Individuele Beoordeling van alle slachtoffers tijdens het eerste persoonlijke contact met de politie. Deze beoordeling heeft als doel om per slachtoffer eventuele beschermingsbehoeften vast te stellen. De maatregel is hevig bekritiseerd - vragen we niet het onmogelijke van de politie? - maar sluit qua uitgangspunt zeker aan bij de universaliteitsgedachte.

\section{Problemen met de huidige slachtofferhiërarchie}

Ik heb zojuist geconstateerd dat kwetsbare slachtoffers binnen het strafrecht nog vaak op basis van het binaire minderhedenmodel worden afgebakend. Dit model wordt geassocieerd met verschillende risico's, waaronder het risico op onder- en overbescherming, vooroordelen, paternalisme en stigma. Ook het Nederlandse rechtssysteem kent vergelijkbare problemen en ik zal dat proberen aan te tonen aan de hand van enkele voorbeelden. Hierbij zal ik mij specifiek op vier problemen richten: 1) het gebrek aan consistentie en transparantie bij de keuze van kwetsbare groepen; 2) de kwalificatie als (niet) kwetsbaar op basis van aannames; 3) het risico op te zware straffen; en 4) nadelige neveneffecten voor de 'kwetsbaren' zelf.

\subsection{Inconsistentie en intransparantie ten aanzien van de afbakening van 'kwetsbaren'}

Allereerst het probleem dat de classificatie van bepaalde groepen als kwetsbaar soms incoherent en weinig transparant gebeurt. Dit probleem laat zich goed illustreren aan de hand 
van de manier waarop de schadevergoeding wordt vormgegeven binnen het strafrecht. Toevallig heb ik mij de laatste tijd veel bezig mogen houden met dit onderwerp. Ik ben namelijk lid van een adviescollege dat in opdracht van de minister voor Rechtsbescherming mag adviseren over het huidige Nederlandse stelsel op dit gebied.

Dit college adviseert onder andere over de voorschotregeling. Wanneer een veroordeelde niet binnen acht maanden na een onherroepelijke uitspraak de toegewezen schadevergoeding heeft betaald aan het slachtoffer, dan vergoedt de staat het openstaande bedrag. In het geval van slachtoffers van ernstige zeden- en geweldsmisdrijven is dit zelfs het volledige openstaande bedrag. Oftewel een ongemaximeerd voorschot. Dat dit behoorlijk in de papieren kan lopen blijkt wel uit de zaak van Jawed W. die twee Amerikaanse toeristen had neergestoken op Amsterdam Centraal. De dader kreeg ook in hoger beroep een schadevergoedingsmaatregel van bijna drie miljoen euro opgelegd. Dit kan de staat dus betalen, want bij Jawed valt weinig te halen. Sinds 2016 kunnen ook andere slachtoffers een beroep doen op de voorschotregeling, maar voor hen geldt een maximum van $€ 5000$. Dit terwijl de daadwerkelijk geleden schade beduidend hoger kan liggen. In het geval van een insolvabele dader staan deze slachtoffers met lege handen voor alle schade die boven de $€ 5000$ uitkomt.

$\mathrm{Nu}$ zou je misschien verwachten dat een dergelijk belangrijk onderscheid, met zulke grote gevolgen voor slachtoffers, is gebaseerd op een goed onderbouwde argumentatie, waarbij nauwgezet is gekeken welke slachtoffers al dan niet onder de ongemaximeerde voorschotregeling vallen. Niets is minder waar. Uit het overzicht van strafbepalingen die toegang geven tot een ongemaximeerd voorschot blijkt dat het a) allemaal opzetdelicten betreft die b) een verband hebben met een inbreuk op de lichamelijke integriteit van het slachtoffer. Maar dat geldt voor meer ernstige strafbare feiten die dan weer niet in de opsomming zijn opgenomen. In de wetsgeschiedenis is echter niets terug te vinden over het waarom van de selectie van deze specifieke strafbepalingen (en andere niet).

En waarom vergoedt de staat bij een ongemaximeerd voorschot het volledige schadebedrag, terwijl slachtoffers zonder bekende dader enkel een beroep kunnen doen op een vaak lagere tegemoetkoming uit het Schadefonds geweldsmisdrijven? Wat rechtvaardigt dit verschil in behandeling van slachtoffers met en zonder bekende dader?

Hoe het college gaat adviseren over deze en andere inconsistenties blijft nog even spannend.... Ik weet zelf ook nog niet waar we gaan landen... Als het goed is, wordt ons rapport rond februari volgend jaar gepresenteerd. Dit is goed nieuws. Nu carnaval is geannuleerd hebben we in die periode in ieder geval iets om naar uit te kijken.

\subsection{Kwalificatie als (niet) extra kwetsbaar gebaseerd op aannames}

Een tweede aandachtspunt betreft de aannames en stereotyperingen die soms ten grondslag lijken te liggen aan de kwalificatie kwetsbaar of 'regulier' slachtoffer. Door deze aannames ontstaan twee risico's. a) Het eerste risico is dat 'gewone' slachtoffers ten onrechte als kwetsbaar worden gekwalificeerd. Dit leidt tot overbescherming. b) De keerzijde is dat 'gewone' slachtoffers onverwacht toch kwetsbaar kunnen zijn. Maar dat die kwetsbaarheid niet wordt onderkend. Dit leidt tot onderbescherming. 
$\mathrm{Ad} \mathrm{a)} \mathrm{In} \mathrm{de} \mathrm{jurisprudentie,} \mathrm{maar} \mathrm{ook} \mathrm{in} \mathrm{beleidsdocumenten} \mathrm{zijn} \mathrm{soms} \mathrm{aanwijzingen} \mathrm{te} \mathrm{vinden}$ dat bepaalde groepen slachtoffers haast automatisch als kwetsbaar worden gezien, gebaseerd op stereotype aannames over zo'n groep.

Een van de meest pregnante voorbeelden die ik ben tegengekomen betreft de volgende passage uit de 2011 OM Strafvorderingsrichtlijn inzake oplichting:

Indien bij oplichting bewust kwetsbare slachtoffers worden uitgekozen dient dit (...) bij de beoordeling van het feit als strafverzwarend te worden beoordeeld. Te denken valt aan personen die de oplichting verminderd kunnen doorzien, zoals (al dan niet verwarde) bejaarden of kinderen. (...) Tenslotte kan gedacht worden aan personen met een klein inkomen (...) die vaak goedgeloviger zijn en bij wie de oplichting extra hard aankomt.

De passage bevat allereerst een vooroordeel ten aanzien van 'bejaarden'. De term 'bejaarden' is al beladen. Ongeacht of deze bejaarden verward zijn, kunnen zij volgens het College van Procureurs-Generaal oplichting verminderd doorzien. Maar ook 'personen met een klein inkomen' staan er gekleurd op. Blijkbaar zijn ook zij goedgeloviger dan anderen. Nu heeft wetenschappelijk onderzoek weliswaar aangetoond dat geldzorgen het denkvermogen tijdelijk kunnen aantasten, maar dat rechtvaardigt nog niet dergelijke vergaande conclusies.

Niet alleen toont de passage aan dat kwetsbaarheid soms wordt gebaseerd op stereotype denkbeelden over groepen, ze is bovendien stigmatiserend. In de meer recente versies van de bewuste Richtlijn is de toelichting gelukkig aangepast, maar daarmee is niet uitgesloten dat deze stereotypen - weliswaar meer op de achtergrond of onbewust - een rol blijven spelen bij personen werkzaam binnen de strafrechtketen.

Ad b) De keerzijde van de medaille is dat er ook groepen slachtoffers zijn die vrijwel standaard als niet-kwetsbaar worden gezien. Dit probleem laat zich bijvoorbeeld illustreren aan de hand van artikel 83 van het Verdrag betreffende de werking van de Europese Unie. Dit artikel bepaalt dat het Europees Parlement en de Raad minimum voorschriften kunnen vaststellen ter bepaling van strafbare feiten en sancties op het gebied van enkele ernstige vormen van criminaliteit met een grensoverschrijdende dimensie.

Deze zogenaamde 'Eurocrimes' betreffen: 'terrorisme, mensenhandel en seksuele uitbuiting van vrouwen en kinderen, illegale drugshandel, illegale wapenhandel, het witwassen van geld, corruptie, de vervalsing van betaalmiddelen, computercriminaliteit en de georganiseerde criminaliteit' (art. 83 lid 1 VWEU).

Opvallende afwezige bij 'mensenhandel en seksuele uitbuiting' zijn natuurlijk de mannelijke slachtoffers. Bestaan er dan geen mannelijke slachtoffers van seksuele uitbuiting? Ja natuurlijk wel, maar we hebben ze veel minder in het vizier.

De perceptie dat mannen minder kwetsbaar zijn dan vrouwen zien we niet alleen terug in wetgeving, maar ook in victimologisch onderzoek. Het victimologisch onderzoek is eveneens eenzijdig gericht bepaalde groepen 'kwetsbaren'. Maarten Kunst wees daar in zijn oratie ook al op. We weten inmiddels bijvoorbeeld vrij veel van vrouwelijke en minderjarige slachtoffers 
van huiselijk en seksueel geweld, maar dit geldt in mindere mate voor mannelijke slachtoffers van deze misdrijven. En ook bepaalde vormen van geweld zijn ernstig onderbelicht.

In dit verband wil ik graag wijzen op het volkomen achterhaalde artikel $316 \mathrm{Sr}$. Op basis van dit artikel geldt er een vervolgingsuitsluitingsgrond ten aanzien van vermogensdelicten gepleegd binnen het huwelijk of het geregistreerd partnerschap. Dit betekent dat huwelijkspartners dus straffeloos van elkaar kunnen stelen, verduisteren, etcetera. Het OM mag de dader immers niet vervolgen. Hoewel fysiek, psychisch en seksueel geweld in afhankelijkheidsrelaties terecht uit de privésfeer zijn gehaald, geldt dit dus niet voor economisch geweld. Dat zit nog stevig verborgen achter de voordeur.

Een motie uit 2015 over dit onderwerp, leidde helaas niet tot een wetswijziging. De toenmalige Staatssecretaris vond dat er geen aanleiding was om de wetgeving te veranderen, onder meer omdat er 'vooralsnog niet [was] gebleken van een omvangrijk probleem waarvoor afschaffen van de vervolgingsuitsluitingsgrond de oplossing is'.

Dat er nog niet was gebleken van een omvangrijk probleem klopt. Economisch geweld in afhankelijkheidsrelaties is in Nederland nog niet onderzocht. Maar het feit dat het nog niet is onderzocht betekent niet dat het in de praktijk geen groot probleem kan zijn. Buitenlandse studies wijzen op hoge prevalentiecijfers en een grote impact op slachtoffers. In het ergste geval kan economisch geweld kan leiden tot armoede en financiële afhankelijkheid van een gewelddadige partner. Wat mij betreft vormt economisch geweld in afhankelijkheidsrelaties dus een echte 'blinde vlek', die hoognodig moet worden aangepakt.

\subsection{Risico op te zware sanctionering}

Het derde probleem betreft het risico dat er te zwaar wordt gestraft. Indien sprake is van een kwetsbaar slachtoffer, dan wordt hier regelmatig naar verwezen in de strafmotivering.

Ook verdachten die misbruik maken van oudere mensen kunnen vaak rekenen op een hogere straf. Neem bijvoorbeeld het arrest van Hof Amsterdam van 27 mei 2013 waarin verdachte wegens diefstal werd veroordeeld tot een onvoorwaardelijke gevangenisstraf van 18 maanden. Het hof overwoog ten aanzien van de straf het volgende:

Met die apparatuur heeft de verdachte eerst de bankgegevens van een op leeftijd zijnde en daarmee kwetsbare vrouw weten te ontfutselen om vervolgens verschillende geldbedragen van haar rekening op te nemen. Het hof rekent de verdachte dit zwaar aan. Naast dit slachtoffer heeft de verdachte ook van andere slachtoffers geldbedragen van hun rekeningen opgenomen met een valse dan wel vervalste betaalpas. (...)

Uit deze passage blijkt allereerst dat het hof de hoge leeftijd van het slachtoffer automatisch lijkt te koppelen aan kwetsbaarheid: “... een op leeftijd zijnde en daarmee kwetsbare vrouw ...". Terwijl onduidelijk blijft in welke zin zij kwetsbaar was.

Nu was deze vrouw ook echt kwetsbaar. Ze was immers in de misleidende praktijken van verdachte getrapt. Maar het is maar de vraag of haar hoge leeftijd hiermee causaal in verband kan worden gebracht. Helemaal nu ook mensen van jongere leeftijd slachtoffer zijn geworden. 
Een probleem met de aanname oud-dus-kwetsbaar is dat ze in de praktijk wordt gelogenstraft door de vele ouderen die niet makkelijk om de tuin te leiden zijn en die qua risico op cyberslachtofferschap niet bijzonder kwetsbaar zijn.

Sterker nog, een recent CBS onderzoek toonde aan dat met name jongeren slachtoffer worden van digitale criminaliteit. In de leeftijdscategorie tot 25 jaar was maar liefst 12 procent van de internetgebruikers in 2018 slachtoffer van cybercrime, tegenover slechts 3 procent van de 65plussers.

Het arrest en deze empirische bevindingen roepen de vraag op wat er qua straftoemeting dient te gebeuren wanneer een oud slachtoffer niet extra kwetsbaar blijkt, maar desondanks toch slachtoffer is geworden. Wat als zij, net als zoveel jongere personen, gewoonweg slachtoffer is geworden, omdat sommige criminelen nu eenmaal geraffineerd te werk gaan? En wat als de impact van het delict op dit oudere slachtoffer gelijk is aan de impact op de jongere slachtoffers? Kunnen we er in dat geval vanuit gaan dat de leeftijd van het slachtoffer geen strafverzwarende rol meer speelt?

Wanneer er meer personen van verschillende leeftijden zijn gevictimiseerd, is het bovendien maar de vraag of de kwetsbaarheid van het oudere slachtoffer voor verdachte van belang is geweest om juist dit slachtoffer te benaderen. Mogelijk heeft verdachte zich lukraak tot een groep mensen gewend, zijn verschillende personen in de 'truc' getrapt, en zijn enkele van deze slachtoffers toevallig op leeftijd, maar andere weer niet. Dit roept de vraag op of er belang moet worden gehecht aan de hoge leeftijd van slachtoffer, wanneer niet kan worden uitgesloten dat de slachtoffers willekeurig zijn gekozen. Is het strafwaardig verwijt dat we deze verdachte kunnen maken hetzelfde als het verwijt dat we een verdachte maken die slachtoffers doelbewust op hun kwetsbaarheid uitzoekt?

Of beogen we bepaalde 'kwetsbare' medeburgers onverkort te beschermen? Ongeacht of ze daadwerkelijk kwetsbaar zijn en ongeacht of hun vermeende kwetsbaarheid een rol heeft gespeeld in de criminele intentie van verdachte? Toegepast op onze casus: kan een verdachte het ten aanzien van een ouder slachtoffer ooit 'goed' doen of zal de hoge leeftijd van het slachtoffer hem altijd in strafverzwarende zin voor de voeten worden geworpen? En zo ja, vanaf welke leeftijd gaat dit eigenlijk een rol spelen?

\subsection{Nadelige neveneffecten voor kwetsbare slachtoffers}

Ik kom aan bij het vierde probleem. Zojuist hebben we het vooral gehad over de voordelen van de kwalificatie als kwetsbaar slachtoffer. Maar deze kwalificatie kan misschien ook nadelen hebben voor de betrokkenen. Het is bijvoorbeeld maar de vraag hoe slachtoffers het kwetsbaarheidslabel zelf ervaren. Hoe denken zij over motiveringen van rechters waarin steeds vaker aandacht wordt besteed aan hun kwetsbaarheid? Wordt dit ervaren als een vorm van erkenning of is dit voor sommige slachtoffers juist pijnlijk? Over gevoelens van stigmatisering vanwege het slachtofferlabel is al een en ander geschreven, maar hoe zit het met gevoelens ten aanzien van het adjectief 'kwetsbaar slachtoffer'? En welke impact heeft identificatie of zelfidentificatie als kwetsbaar bijvoorbeeld op angstgevoelens of een fenomeen als victim blaming? 
Een andere negatieve bijwerking zou kwetsbaarheid als self-fulfilling prophecy kunnen zijn. Hoe meer de gedachte in de gemeenschap postvat dat bijvoorbeeld ouderen per definitie kwetsbaar zijn, des te aantrekkelijker worden ouderen als doelwit voor berekenende criminelen, niet-kwetsbare ouderen daarbij inbegrepen. Zo kom je in een soort vicieuze cirkel terecht.

Daarnaast kunnen kwetsbare slachtoffers te maken krijgen met paternalisme of maatregelen die juist in hun nadeel werken. Neem bijvoorbeeld de bedenktijd bij zedenfeiten. Wanneer een slachtoffer van seksueel geweld zich meldt bij de politie wordt niet meteen overgegaan tot aangifte, maar wordt er eerst een informatief gesprek gevoerd. Na afloop van het informatieve gesprek wordt het slachtoffer een bedenktijd aangeboden, voordat hij of zij kan overgaan tot aangifte. De ratio van deze bedenktijd ziet op het feit dat het hier bijzondere strafbare feiten betreft. Het strafproces kan een nog grotere impact hebben op zedenslachtoffers, mede omdat hun directe omgeving betrokken kan worden in het onderzoek. Dit geldt vooral wanneer verdachte en slachtoffer bekenden zijn van elkaar.

Sinds 2015 is deze bedenktijd niet langer verplicht, maar kan het slachtoffer aangeven hiervan af te willen zien. Een rapport uit 2020 van de Inspectie Justitie \& Veiligheid toonde echter aan dat zedenrechercheurs de bedenktijd presenteren als een standaard werkwijze met een standaard duur van 1 à 2 weken. Zelfs wanneer slachtoffers de voorkeur geven aan direct aangifte doen. Uit het rapport blijkt overigens ook dat zedenrechercheurs met de beste intenties handelen, maar dat hun handelingen dus niet altijd overeen komen met de behoeften van slachtoffers.

\section{Conclusie}

Ik komt tot een conclusie. $\mathrm{Er}$ is in toenemende mate aandacht voor de verschillende kwetsbaarheden van slachtoffers binnen het strafrecht. En dit is een goede zaak! Ik ben zojuist misschien wat streng geweest, maar ik denk dat we deze ontwikkeling vooral moeten toejuichen. Echter, omdat kwalificatie als kwetsbaar zulke belangrijke gevolgen kan hebben voor het slachtoffer - maar ook voor verdachte en de sanctionering - zou het onderscheid tussen 'kwetsbare' en 'minder kwetsbare' slachtoffers goed moeten worden doordacht. Ik heb geprobeerd aan te tonen dat dat momenteel niet altijd gebeurt. Het onderscheid is niet altijd consistent of transparant, lijkt soms gebaseerd op stereotypen, kan leiden tot te zware straffen en het kan gepaard gaan met nadelige consequenties voor de kwetsbare slachtoffers zelf.

Ik roep nog even het gedicht van Lucebert in herinnering:

\section{alles van waarde is weerloos wordt van aanraakbaarheid rijk en aan alles gelijk}

Voor mij komt in deze strofe tot uiting wat ik gedurende de afgelopen 40 minuten heb geprobeerd duidelijk te maken. 
Ten eerste dat alles van waarde weerloos is.

Ja, typisch zijn juist de meest waardevolle zaken in het leven het meest kwetsbaar. Dit geldt ook voor belangrijke beginselen als rechtsgelijkheid en een gebalanceerde afweging van kwetsbare slachtofferbelangen met andere belangen. We zullen voor een aantal slachtofferrechten nog lange tijd aangewezen blijven op het identificeren van kwetsbare groepen, zelfs wanneer we steeds meer richting het universaliteitsmodel zouden bewegen. Hoe kunnen we er dan voor zorgen dat deze groepen zorgvuldig worden gekozen zonder dat we ons per ongeluk schuldig maken aan goede-bedoelingen-discriminatie?

Welnu, om dit te voorkomen zullen we meer onderzoek moeten verrichten naar kwetsbaarheden in de context van het strafrecht. We moeten bijvoorbeeld een gestructureerde inventarisatie maken van de huidige 'kwetsbaarheden', de ratio achter de selectie van deze kwetsbaarheden en de mate waarin die ratio is gebaseerd op wetenschappelijk onderzoek. Ook dient de 'match' tussen een bepaalde kwetsbaarheid en een daaraan gekoppelde maatregel in kaart te worden gebracht. Welke kwetsbaarheid beoogt de maatregel nu precies te verhelpen en doet ze dat ook in de praktijk? Daarbij moeten we beducht zijn voor stereotypes en moeten we oog hebben voor het feit dat we bepaalde 'kwetsbaren' nog onvoldoende in het vizier hebben. Zodra de relevante kwetsbaarheden zijn geïdentificeerd worden ze tastbaar. Of 'aanraakbaar' volgens het gedicht. Dan kunnen we ze afwegen tegen andere belangen en ze op gepaste wijze adresseren.

En die gepaste reactie zou zeker in de sleutel van de gelijkheid moeten worden geplaatst. Wordt van aanraakbaarheid rijk en aan alles gelijk. Of Lucebert de 'gelijkheid' in deze dichtregel positief bedoelt, betwijfel ik. Maar het streven naar gelijkheid zou bij het zoeken naar een evenwichtig en consistent stelsel van kwetsbaarheden juist wel een goed uitgangspunt kunnen zijn. We moeten op zoek naar manieren om het speelveld voor alle slachtoffers gelijker te maken.

Maar goed, er moet dus vooral nog veel onderzoek worden verricht. In mijn oratie heb ik vooral veel vragen opgeworpen en weinig vragen beantwoord. Een deel van die openstaande vragen ga ik verwerken in een VIDI voorstel. Met behulp van een rechtsvergelijkend, subdisciplinair en interdisciplinair onderzoek ga ik proberen het 'kwetsbare slachtoffer' binnen het strafrecht van een steviger empirische en normatieve basis te voorzien. Ik hoop in samenwerking met andere wetenschappers en de praktijk te kijken wat we, binnen de grenzen van het haalbare, kunnen verbeteren. Hierbij zal ik zeker een beroep doen op het VINE netwerk en het COST Action netwerk inzake cultural victimology. Maar ik nodig allen die geïnteresseerd zijn in dit onderwerp uit om vooral contact op te nemen. Zodat we samen kunnen komen tot een kennisgestuurde emancipatie van kwetsbare slachtoffers in het strafrecht. 


\section{Dankwoord}

Beste dames en heren, dit was het inhoudelijke gedeelte van mijn oratie. Maar ik wil tot slot graag even stilstaan bij diegenen die aan mijn loopbaan en benoeming hebben bijgedragen.

In de eerste plaats wil ik natuurlijk het College van Bestuur en het faculteitsbestuur, en dan met name Rianne Letschert en Jan Smits, bedanken voor het in mij gestelde vertrouwen. lets later dan oorspronkelijk gepland, maar ik aanvaard mijn benoeming nog steeds met veel blijdschap en trots.

Beste Rianne, ik wil jou ook nog even in het bijzonder bedanken, omdat je me destijds bij INTERVICT een positie als UD hebt aangeboden. Je bent een inspirerend en warm mens en een prachtig voorbeeld van positief leiderschap. Ik ben je natuurlijk niet voor niets achterna gereisd naar Maastricht. Ik kon je gewoon niet missen.

Beste Marc en Frans-Willem, ik ben jullie dankbaar voor alle steun en advies die jullie me als promotores hebben gegeven. Marc, aan jou heb ik op professioneel gebied bijzonder veel te danken. Als jij me niet bepaalde kansen had geboden of mij op kansen had gewezen dan had ik hier vandaag niet gestaan. Je bent op het gebied van de slachtofferrechten en het strafrecht een absolute autoriteit. En ik had me geen betere of vriendelijker promotor - en later mentor - kunnen wensen. Dankjewel daarvoor.

Beste oud-collega's van INTERVICT en andere collega's van Tilburg University. Ik zal Tilburg altijd een warm hart toedragen en dat zit hem in de fantastische mensen waar ik al die jaren mee heb mogen samenwerken. Ik mis jullie stiekem nog steeds. Maar ik voorspel dat we na corona snel weer eens het glas zullen heffen. En weer zullen dansen.

Beste Hans en André, jullie ben ik natuurlijk dankbaar voor de prachtige kans om binnen jullie capgroep hoogleraar te mogen zijn. Ik had na al die jaren victimologie toch een kleine achterstand opgelopen op het gebied van het strafrecht in den brede. Jullie hebben desondanks de gok gewaagd en mij de leerstoel gegund. Heel veel dank voor jullie vertrouwen.

Ik prijs mij ook gelukkig met alle andere collega's van de capgroep Strafrecht \& Criminologie. Ik voelde mij vanaf dag één thuis in jullie midden en dat is bijzonder. Dat ik na INTERVICT wederom in een interdisciplinaire, internationale maar vooral ook humorvolle en warme omgeving ben beland beschouw ik als een groot geluk. Ik kijk ernaar uit de krachten te bundelen in mooie nieuwe onderzoeksprojecten en memorabele capgroepuitjes.

Beste Monique, Maryna en Modeste. Jullie zijn alle drie pas net begonnen aan jullie AIOtraject, maar ik weet nu al dat jullie barsten van het talent en dat ik de komende jaren vooral veel van jullie zal leren. Ik ben vereerd dat ik jullie co-promotor mag zijn.

Beste studenten, ik weet dat enkelen van jullie nu kijken, dus ik wil ook een paar woorden tot jullie richten. Jullie lesgeven is een absoluut voorrecht en ik geniet van jullie openheid, kennis en enthousiasme. Ook wil ik jullie complimenteren met de door jullie getoonde flexibiliteit en veerkracht in deze lastige tijd. 
Lieve pap en mam. Ik ben ontzettend blij dat jullie hier allebei aanwezig zijn. Ik ben jullie dankbaar voor jullie onvoorwaardelijke steun, en voor jullie warme en ontspannen opvoeding. Jullie wisten mijn leergierigheid altijd te stimuleren, zonder daaraan hooggespannen verwachtingen te koppelen. Mam, ik heb jou onbedoeld wat stress bezorgd de afgelopen weken, maar je kunt vanaf nu weer met een gerust hart slapen. Het is uiteindelijk allemaal goed gekomen met die toga...

Lieve Simon, lieve Ava, ik ben ook heel erg blij dat jullie er vandaag bij zijn. Ik weet dat jullie stiekem al uitkijken naar de McDrive, maar houd moed! Nog even en dan komen de drie verlossende woorden...

Het laatste woord is uiteraard voor Rob. Lieve Rob, enkele aanwezigen hier hebben wel eens beweerd dat ik geen leerstoel bekleed, maar een hangmat. Maar jij weet als geen ander dat deze baan ook druk en stressvol kan zijn. Jij hebt mij - zeker de laatste weken - de tijd gegund voor mijn werk. Daar ben ik je dankbaar voor. Maar ik wil jou en de kinderen vooral bedanken voor het feit dat jullie mij iedere dag laten zien wat echt van waarde is. Ik hou van jullie.

Ik heb gezegd. 